\title{
KÜLÖNBÖZŐ TÍPUSÚ FELÜLETAKTÍV ANYAGOK OLDHATÓSÁGÁNAK TITRIMETRIÁS JELLEMZÉSE
}

\section{TITRIMETRIC CHARACTERIZATION OF THE SOLUBILITY PROPERTIES OF VARIOUS SURFACTANTS}

\author{
Nagy Roland ${ }^{1}$ Kothencz Réka ${ }^{2}$, Varga Csilla ${ }^{3}$, Bartha László ${ }^{4}$ \\ Pannon Egyetem, Mérnöki kar, MOL Ásványolaj-és Széntechnológiai Intézeti Tan- \\ szék, Cím: 8200, Magyarország, Veszprém, Egyetem utca 10. \\ Inroland@almos.uni-pannon.hu \\ ${ }^{2}$ kothenczr@almos.uni-pannon.hu \\ 3 vcsilla@almos.uni-pannon.hu \\ 4bartha@almos.uni-pannon.hu
}

\begin{abstract}
In recent decades due to the rapid development of household chemicals and cosmetic industry, the research of surfactants has become increasingly important. Therefore, all type of surfactants has been used in more and more areas. Our aim was to examine if the new titration method can be also suitable for the determination of water number of various surfactants used in petroleum industry and in polymer composites. A correlation analysis was performed with the water numbers measured by the new method. It was found that the solubilty properties can be appropriate for further application.
\end{abstract}

Keywords: nonionic surfactants, compatibilizing additives, solubility, method development

\section{Összefoglalás}

Az utóbbi évtizedekben a háztartásvegyipar és a kozmetikai ipar fejlödésével, a felületaktív anyagokkal kapcsolatos kutatások egyre nagyobb jelentőségüvé váltak, ezért egyre több területen alkalmazzák őket. Méréseink során annak a vizsgálata volt célunk, hogy a saját fejlesztésü, új titrimetriás módszer alkalmas-e különböző típusú, kőolajipari célú felületaktív anyagok oldhatósági jellemzőinek meghatározására. Megállapítottuk, hogy az új módszer megbízhatóan alkalmazható a különböző kémiai szerkezetü tenzidek vízben való oldhatóságának jellemzésére és hasznos információt nyújthatnak a további felhasználás szempontjából.

Kulcsszavak: nemionos tenzid, kompatibilizáló adalék, oldhatóság, módszerfejlesztés

\section{Bevezetés}

Az utóbbi évtizedekben a háztartásvegyipar és a kozmetikai ipar rohamos fejlödésével párhuzamosan a tenzidekkel kapcsolatos elméleti és gyakorlati kutatások egyre nagyobb jelentőségüvé váltak. Azon- ban a tenzideket nemcsak ez a két iparág alkalmazza, hanem polimer kompozitok előállításához is egyre nagyobb mennyiségben használják fel [1, 2].

A tenzidekkel hidratált keményítőt széles körben alkalmazzák biopolimer keverékek előállítására, amelyek olcsók és megfelelő lebomlási tulajdonságokkal rendelkez- 
nek [3]. Jelenleg karbamid-formaldehid vagy fenol-formaldehid alapú tenzidekkel stabilizált emulzió típusú ragasztókat használnak a fa ragasztóanyagaként [4].

Az emulgeátorokkal szembeni követelményeket az alkalmazott terület többitől eltérő sajátosságai szabják meg. A tenzidmolekulák amfipatikus jellegéböl adódóan egyik kiemelt fontosságú tulajdonságuknak a vízben vagy olajban való oldhatóságuk tekinthető. Ezt a jellemzőt a felhasználási cél és terület kiválasztásához szintén szükséges volt meghatározni.

Munkánk során célunk az volt, hogy több adalékcsalád jellemzőit, föként a vízben és szerves oldószerben való oldhatóságát egy általánosan alkalmazható laboratóriumi módszerrel határozzuk meg. Ennek során egy korábban továbbfejlesztett titrimetriás módszer szélesebb körü használatának lehetőségét kívántuk megvizsgálni. Fontos szempontként tartottuk szem előtt olyan gyors és egyszerü módszer alkalmazását, amely egyúttal precíz mérési eredményeket szolgáltat. Ennek érdekében a szakirodalomból ismert empirikus számítási módszerrel ellenőriztük az adatok pontosságát. Ezek megfelelösége esetén a módszer ugyanis már alkalmasnak minősíthető a vizsgált felületaktív anyagok oldhatóságának jellemzésére.

\section{Felhasznált anyagok}

A Pannon Egyetem Vegyészmérnöki és Folyamatmérnöki Intézetének MOL Ásványolaj- és Széntechnológiai Intézeti Tanszékén évek óta intenzív kutatás folyik kőolajipari célú felületaktív anyyagok kifejlesztése céljából. Ennek keretében, a saját fejlesztésű tenzidek és felületaktív adalékok minősítésére alkalmas vizsgálati módszerek kidolgozását is el kellett végeznünk. E kutatás részeként került előtérbe egy, a tenzidek vízben való oldhatóságával és az adalékok szerves oldószerben való oldhatóságával kapcsolatos jellemző megbízható mérésé- nek igénye. Ilyen mérési módszer kidolgozásának lehetőségeként megvizsgáltuk, hogy a rendelkezésünkre álló AvaSpec gyártmányú száloptikás spektrofotométer használata alkalmas lehet-e a felületaktív anyagok vízben való oldhatóságának a jellemzésére.

A vizsgálat során felhasznált kísérleti adalékok jellemzőit az 1. táblázat tartalmazza.

1. táblázat. Vizsgált adalékok fizikai kémiai jellemzö $i$

\begin{tabular}{|c|c|c|c|c|c|}
\hline & T-1 & T-2 & T-3 & $T-4$ & T-5 \\
\hline $\begin{array}{l}\text { Vegyül } \\
\text { et típus }\end{array}$ & $\begin{array}{l}\text { zírsav- } \\
\text { poliol } \\
\text { észter }\end{array}$ & $\begin{array}{l}\text { Olajsav } \\
\text {-poliol } \\
\text { észter }\end{array}$ & $\begin{array}{l}\text { Olefin- } \\
\text { MSA } \\
\text { kopoli- } \\
\text { mer- } \\
\text { amin só }\end{array}$ & $\begin{array}{c}\text { Gliceri } \\
\mathrm{n}- \\
\text { monool } \\
\text { eát } \\
\text { észter }\end{array}$ & \begin{tabular}{|c|} 
Olefin \\
-MSA \\
kopoli \\
-mer- \\
amin \\
só \\
\end{tabular} \\
\hline $\begin{array}{l}\text { Savszá } \\
\text { m, mg } \\
\text { KOH/g }\end{array}$ & 23,5 & 4,6 & 51,4 & 118,4 & 38,9 \\
\hline $\begin{array}{l}\text { Elszap- } \\
\text { panosít } \\
\text { ási } \\
\text { szám, } \\
\text { mgKO } \\
\mathrm{H} / \mathrm{g}\end{array}$ & 119,3 & 177,2 & 189,9 & 171,0 & $\begin{array}{c}158, \\
2\end{array}$ \\
\hline \begin{tabular}{|l}
$\mathrm{KV}$, \\
$100^{\circ} \mathrm{C}$ \\
$\mathrm{mm}^{2} / \mathrm{s}$ \\
\end{tabular} & 8,83 & 13,33 & $>500$ & 8,8 & $>500$ \\
\hline
\end{tabular}

\section{Alkalmazott módszer, módszer- fejlesztés}

A vizsgálathoz egy Avaspec 2048 Standard száloptikás spektrofotométert használtunk Avalight-DHc Compact Halogen fényforrással (1. ábra).

Spektrofotométer jellemzői:

- Optikai szint: Szimmetrikus CzernyTurner, 75 mm gyújtótávolság;

- Hullámhossz tartomány: 200-1100 nm;

- Felbontás: 0,04-20 nm;

- Detektor: CCD lineáris, 2048 pixel.

Fényforrás jellemzői:

- Hullámhossz tartomány: 200-2500 nm; 
- Stabilitás: $<1$ mAU;

- Optikai teljesítmény (a szálban): $7 \mu \mathrm{W}$;

- Hőmérséklet tartomány: $5-35^{\circ} \mathrm{C}$.

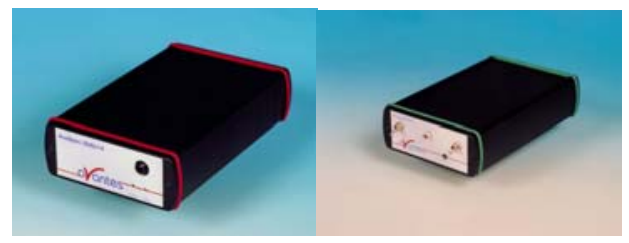

1. ábra. A spektrofotométer és a fényforrás

A szakirodalomban ismertetett módszer továbbfejlesztésénél az volt a célunk, hogy egy új vízszám mérési módszert dolgozzunk ki, aminek alkalmazásából származó HLB értékek az irodalmi adatokkal összehasonlítva pontosabb elemzést tesz lehetővé [5-7]. Az amfipatikus molekulák hidrofilitásának ill. lipofilitásának mértékét a HLB-érték jellemzi (hidrofil-lipofil egyensúly).

A kutatásaink során Becher és munkatársai által javasolt eljárás alapján határoztuk meg a vízszám értéket. Az eredeti módszerhez használt benzol oldószer helyett ciklohexánt alkalmaztunk és a nehezen érzékelhető vizuális végpontjelzést fotometriás detektálással váltottuk fel. Az általunk kidolgozott új mérési eljárás kivitelezése során a vizsgálandó anyagot elözőleg elkészített ciklohexán-dioxán (4\% ciklohexán tartalom) elegyben oldottuk fel. Ezután az így előkészített mintát desztillált vízzel titráltuk és spektrofotométer segítségével folyamatosan mértük a transzmittancia értékeket. A desztillált vizet addig adagoltuk az adalékot tartalmazó oldatba, amíg az tartósan zavarossá vált, és a transzmittancia értékek a további víz adagolására sem csökkentek radikálisan.

A mérési adatok kiértékelésénél a rögzített pillanatnyi transzmittancia értékeket ábrázoltuk a titráló desztillált víz térfogatok $\left(\mathrm{cm}^{3}\right.$-ben) függvényében. Az így kapott görbe ekvivalencia pontja megfelel a vizs- gált adalék relatív oldhatósági értékének, amelyből a HLB érték számolható.

\section{Mérési eredmények}

A bemutatott módszer használatát felületaktív adalékanyagok vizsgálatára is kiterjesztettük, melyek eredményei a 2. táblázatban találhatók.

2. táblázat. Vizsgált adalékok oldhatósági jellemzöi

\begin{tabular}{|l|c|c|c|c|c|}
\hline & T-1 & T-2 & T-3 & T-4 & T-5 \\
\hline $\begin{array}{l}\text { Vízben } \\
\text { való } \\
\text { oldhatóság } \\
\text { (\%) }^{1}\end{array}$ & 55 & 16 & 0 & 42 & 0 \\
\hline $\begin{array}{l}\text { Szerves } \\
\text { oldószerben } \\
\text { való } \\
\text { oldhatóság } \\
\text { (\%) }^{2}\end{array}$ & 100 & 100 & 100 & 100 & 100 \\
\hline $\begin{array}{l}\text { Vízszám } \\
\text { (C/D) }^{3}\end{array}$ & 11,1 & 6,5 & 5,1 & 8,8 & 2,9 \\
\hline HLB $^{4}$ & 15,3 & 5,6 & 6,2 & 9,0 & 3,1 \\
\hline $\begin{array}{l}\text { HLB } \\
\text { (C/D) }^{5}\end{array}$ & 14,0 & 6,5 & 4,2 & 10,3 & 0,5 \\
\hline $\begin{array}{l}\text { HLB szám } \\
6\end{array}$ & 13,8 & 5,6 & 2,8 & 9,0 & 1,7 \\
\hline HLB $^{7}$ & 0,2 & 0,9 & 0,4 & 1,3 & 1,2 \\
\hline
\end{tabular}

${ }^{1}$ Adalék $1 \%$-os desztillált vizes oldatának transzmittancia értéke (Referenciák: $100 \%$ desztillált víz, $0 \%$ nincs fényáteresztés)

${ }^{2}$ Adalék 1\%-os toluolos oldatának transzmittancia értéke (Referenciák: $100 \%$ toluol, $0 \%$ nincs fényáteresztés)

${ }^{3} \mathrm{C} / \mathrm{D}=$ Ciklohexán/Dioxán elegy felhasználásával mért vízszám

${ }^{4}$ A klasszikus vízszám meghatározásán alapuló módszerrel (benzol/dioxán elegyben) mért adatok

${ }^{5} \mathrm{C} / \mathrm{D}=$ Ciklohexán/Dioxán elegy felhasználásával végzett mérés

${ }^{6}$ számítással meghatározott HLB érték

${ }^{7} \mathrm{HLB}_{\text {szám }}-\mathrm{HLB}_{\mathrm{C} / \mathrm{D}}$

A mérési adatokból jól látszik, hogy a korábbi módszerrel meghatározott HLB érték nagy eltérést mutat az irodalmi HLB értékhez képest. Ezért volt szükség a meglévő módszer továbbfejlesztésére. Az új, kísérleti módszerrel meghatározott vízszám érték lényegesen kisebbnek adódott. Ezután 
meghatároztuk a HLB értéket és az elméleti HLB értéket is, amely segítségével a $\triangle$ HLB értéket kiszámítottuk.

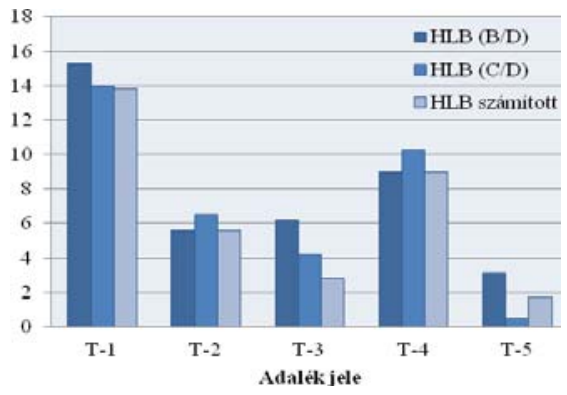

2. ábra. Adalékok HLB értéke

Az eredmények alapján (2. ábra) megállapítottuk, hogy a numerikus úton, illetve a kísérleti módon meghatározott HLB közötti különbség jelentősen csökkent. Tehát az új módszer a vizsgált adalékok számított HLB értékét a benzol-dioxán elegyben mérteknél jobban közelíti. Az összehasonlításból jól látszik, hogy az általunk kidolgozott új mérési módszerrel mért adatok a szakirodalmi értékeket is jobban közelítik.

\section{Következtetések}

A korábban kidolgozott vízszám meghatározó módszert a különböző szerkezetü adalékok vizsgálatára is kiterjesztettük. Megállapítottuk, hogy az új módszer az eddig alkalmazott módszernél lényegesen jobban megközelíti a számított módszerrel meghatározott értékeket. Így a fejlesztés segítségével sikerült a kísérleti adalékok oldhatóságára jellemző HLB értékeket a korábbinál nagyobb pontossággal meghatározni. Ennek igazolására további vizsgálatok is szükségesek.

\section{Szakirodalmi hivatkozások}

[1] Laurier L. Schramm: Surfactants: Fundamentals and applications in the petroleum industry, Cambridge University Press, 2000

[2] D. J. Shaw: Introduction to Colloid and Surface Chemistry, Butterworth-Heinemann, 1992

[3] Jeffrey A. Byars, George F. Fanta, James A. Kenar: Effect of amylopectin on the rheological properties of aqueous dispersions of starch-sodium palmitate complexes, Carbohydrate Polymers 95, 2013, 171-176

[4] Zhaofeng Li, Jian Wang, Li Cheng, Zhengbiao Gu, Yan Hong, Agnieszka Kowalczyk: Improving the performance of starch-based wood adhesive by using sodium dodecyl sulfate, Carbohydrate Polymers 99, 2014, 579-583

[5] Roland Nagy, Réka Kothencz, Rubina Sallai, László Bartha: An improved method for the determination of HLB properties of nonionic surfactants, International Journal of Scientific and Engineering Research, Volume 6, Issue 3, March 2015

[6] Réka Kothencz, Roland Nagy, László Bartha: Study on the solubility properties of surfactant mixtures, 16. Austrian Chemistry Days, 2015, Innsbruck, Ausztria

[7] Yiangying $\mathrm{Wu}, \quad$ Yuming $\mathrm{Xu}, \quad$ Tadeusz Dabros, Hassan Hamza: Development of a method for measurement of relative solubility of nonionic surfactants, Colloids and Surfaces A: Physicochem. Eng. Aspects 232, 2004, 229-237

\section{Köszönetnyilvánítás}

A szerzők köszönetet mondanak a cikk elkészítéséért: MOL Nyrt., Csoportszintü Kutatás \& Üzletfejlesztés támogatásáért.

\section{MOL}

